The Conquest of Tuberculosis 



\section{Selman A.Waksman}

\section{The Conquest of}

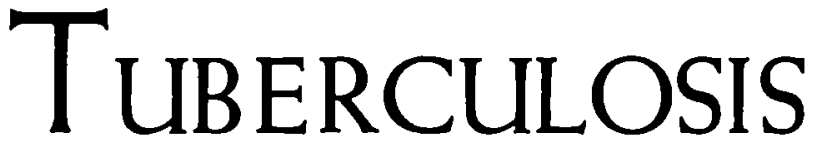

UNIVERSITY OF CALIFORNIA PRESS

BERKELEY AND LOS ANGELES 1964 
University of California Press

Berkeley and Los Angeles, California

Cambridge University Press

London, England

(c) 1964 by The Regents of the University of California Library of Congress Catalog Card Number: 64-21065

Printed in the United States of America 
"If I had tuberculosis...

this idea, formerly terrifying, no longer makes anyone tremble... antibiotics have appeared, sanatoria have disappeared; as far as the public is concerned the problem is solved, the disease has been conquered."

International Union against Tuberculosis, January, 1962 

TO THE SURGEONS AND PHYSICIANS OF THIS AND OTHER COUNTRIES, WHO HAVE TAKEN ADVANTAGE OF THE DISCOVERY OF ANTIBIOTICS, LIKE THE ONE DESCRIBED IN THIS BOOK, TO IMPROVE THE HEALTH OF MAN AND TO CURE INFECTIOUS DISEASES, THIS BOOK IS DEDICATED. 
